\title{
Milk flow-controlled changes of pulsation ratio and pulsation rate affect milking characteristics in dairy cows
}

\author{
Sarah Ambord and Rupert M Bruckmaier* \\ Veterinary Physiology, Vetsuisse Faculty, University of Bern, 3001 Bern, Switzerland
}

Received 24 September 2008; accepted for publication 12 January 2009; first published online 2 March 2009

\begin{abstract}
To test a system with milk flow-controlled pulsation, milk flow was recorded in 29 Holstein cows during machine milking. The three different treatments were routine milking (including a pre-stimulation of 50-70 s), milking with a minimum of teat preparation and milking with milk flow-controlled b-phase, i.e. with a gradually elongated b-phase of the pulsation cycle with increasing milk flow rate and shortening again during decreasing milk flow. For data evaluation the herd was divided into three groups based on the peak flow rate at routine milking (group 1: $<3 \cdot 2 \mathrm{~kg} / \mathrm{min}$; group 2: $3 \cdot 2-4.5 \mathrm{~kg} / \mathrm{min}$; group $3:>4 \cdot 5 \mathrm{~kg} / \mathrm{min}$ ). Compared with routine milking, milking with milk flow-controlled b-phase caused a significant elevation of the peak flow rate and the duration of incline lasted longer especially in cows with a peak flow rate of $>3 \cdot 2 \mathrm{~kg} / \mathrm{min}$ in routine milking. In milking with a minimum of teat preparation the duration of incline lasted longer compared with the two other treatments. Bimodality of milk flow, i.e. delayed milk ejection at the start of milking, was most frequent at milking with a minimum of teat preparation. No significant differences between routine milking and milking with milk flow-controlled b-phase were detected for all other milking characteristics. In summary, milking with milk flow-controlled b-phase changes the course of milk removal, however mainly in cows with high peak flow rates.
\end{abstract}

Keywords: Flow-controlled pulsation, peak flow rate, b-phase.

In dairy cows only about $20 \%$ of the milk is stored in the cisternal cavity and is directly available before milk ejection (Bruckmaier et al. 1994b; Pfeilsticker et al. 1996; Ayadi et al. 2003, 2004). The main portion of the milk is located in the alveoli and small milk ducts and can be extracted only after milk ejection has shifted it into the cistern. The induction of milk ejection requires tactile stimulation of the teats and/or the udder which causes the release of oxytocin and hence myoepithelial contraction and alveolar milk ejection (Bruckmaier \& Blum, 1996; Bruckmaier, 2005). Pre-stimulation induces the milk ejection already before the start of milking, whereas milking without pre-stimulation leads to a transient reduction (bimodality) of milk flow after removal of the cisternal milk and before the availability of alveolar milk which is ejected in response to the stimulation by the teat cup liner during the normal milking procedure (Schams et al. 1984; Bruckmaier \& Blum, 1996; Weiss et al. 2003; Sandrucci et al. 2007). Milk ejection continues throughout the whole milking (Bruckmaier et al. 1994a; Weiss et al. 2003) and, towards the end of milking, the transfer of milk into the

*For correspondence; e-mail: rupert.bruckmaier@physio. unibe.ch cistern can be a limiting factor for the milk flow rate (Pfeilsticker et al. 1995).

Peak milk flow rate (PFR) can be modified by changes of the pulsation ratio (Pfeilsticker et al. 1995; Hamann \& Mein, 1996). The same is true to a limited extent for the average milk flow (AMF) and consequently for the total milking time. While a higher PFR does not necessarily mean a faster udder emptying throughout the milking process, a higher AMF leads to a shorter total milking time at a given amount of milk stored in the udder (Smith \& Petersen, 1946; Thomas et al. 1991; Pfeilsticker et al. 1995; Gleeson et al. 2004).

The objective of this present study was to test the hypothesis that milking with milk flow-controlled changes of the b-phase of the pulsation lead to a faster milk removal than standard pulsation which remains unchanged throughout milking.

\section{Materials and Methods}

Animals and housing

Twenty-nine Holstein cows in early (7), mid (14) and late (8) lactation from a private farm in Switzerland were used 
(early: 1-100 d post partum (p.p.), mid: 101-200 d p.p., late lactation: 200-370 d p.p.). During the experiment the cows were in their first (9), second (2), third (9), fourth (7), sixth (1) and seventh (1) lactations.

Mean 305-d milk-production was $8945 \mathrm{~kg}$ and ranged from $5095 \mathrm{~kg}$ to $10968 \mathrm{~kg}$ in the preceding lactation of the 20 multiparous cows. The animals were kept in a loose housing stall on cleft floor and fed with $40 \%$ maize silage, $10 \%$ sugar beet silage, $35 \%$ green silage, $8 \%$ hay and concentrate (approximately $7 \%$ soy pellets and a cereal mix), according to their individual production levels.

\section{Milking and milk-flow recording}

Cows were milked in a low-level $1 \times 6$ side-by-side-milking parlour with a Lemmer-Fullwood SBS Arizona Group MM95 CE (6344 Meierskappel, Switzerland) at a vacuum level of $40.5 \mathrm{kPa}$ and with a $4 \times 1$ pulsation. Times of milking were in the morning from $5 \cdot 45$ (i.e. $13 \mathrm{~h}$ after previous milking) and in the evening from 16.45 (i.e. $11 \mathrm{~h}$ after previous milking). All milkings were performed by the same person. The liner used was a Lemmer-Fullwood CTF 720138 (6344 Meierskappel, Switzerland).

The experiment included 18 milkings (9 d) and milk flow curves of all milkings were recorded with mobile milk-flow recording units (LactoCorder ${ }^{\circledR}$, WMB AG, 9436 Balgach, Switzerland).

Udder preparation, pre-stimulation and milking routine $(P S+)$ : The milker wore Nitril gloves during milking. After entering the parlour teats of all cows were foamed with Dermaline (5-20\% anionic surfactant, $1-5 \%$ glycerol, $1-5 \%$ anionic tenside, perfume and triclosan; CID LINES NV/SA, 8900 leper, Belgium) and thereafter dried with a single-use paper. Subsequently the clusters were attached without pre-stripping. The process of this routine was always similar and lasted 50-70 s from the first touch of the udder until cluster attachment. After cluster attachment a 35-s high-frequency pre-stimulation was applied (pulsation rate: 250 cycles/min; pulsation ratio: $25: 75)$. As soon as the metering box was not completely filled within $35 \mathrm{~s}$ (i.e. $<200 \mathrm{~g}$ milk within $35 \mathrm{~s}$ ) the clusters were removed automatically with a delay of about $1 \mathrm{~s}$.

Milk flow controlled b-phase $(M B+)$ : The milking machine used was equipped with a special option to adjust the b-phase of the pulsation on the basis of the current milk flow rate as shown in Table 1 . This adjustment caused changes of pulsation ratio and pulsation rate. Overall the adjustments cause longer liner-open periods during phases with high milk flow. A-, c- and d-phases of the pulsation curve remained unchanged.

\section{Treatments}

$P S+/ M B-:$ In this treatment the pulsation ratio was $60: 40$ and the pulsation rate was 55 cycles/min which
Table 1. The milking machine settings and their changes when milked with milk flow-controlled b-phase

$\begin{array}{llll}\begin{array}{l}\text { Milk flow rate, } \\ \mathrm{kg} / \mathrm{min}\end{array} & \begin{array}{l}\text { Pulsation } \\ \text { ratio }\end{array} & \begin{array}{l}\text { Pulsation rate, } \\ \text { cycles/min }\end{array} & \begin{array}{l}\mathrm{a}-+\mathrm{b}-\text { phase, } \\ \mathrm{ms}\end{array} \\ 0-2 \cdot 0 & 60 / 40 & 55 & 655 \\ 2 \cdot 0-2 \cdot 5 & 63 / 37 & 53 & 713 \\ 2 \cdot 5-3 \cdot 0 & 65 / 35 & 51 & 765 \\ 3 \cdot 0-3 \cdot 5 & 68 / 32 & 48 & 850 \\ 3 \cdot 5-4 \cdot 0 & 70 / 30 & 45 & 933 \\ 4 \cdot 0-4 \cdot 5 & 73 / 27 & 43 & 1019 \\ 4 \cdot 5-5 \cdot 0 & 74 / 26 & 42 & 1057 \\ 5 \cdot 0+ & 75 / 25 & 42 & 1071\end{array}$

remained unchanged throughout the entire milking. Cows were milked with the usual milking routine and without milk flow-controlled b-phase on days 2, 6 and 9 of the study.

$P S+/ M B+$ : The routine udder preparation was performed and the cows were milked with milk flow-controlled b-phase on days 3, 5 and 8 .

$P S-/ M B-$ : This treatment included a minimum of teat cleaning. First the teats of all 6 cows in the parlour were foamed, then one cow after the other was cleaned within some seconds with a single-use paper and the cluster was attached immediately. Milking was performed without milk flow-controlled b-phase. The clusters were removed automatically. This treatment was used on days 1, 4 and 7 of the study.

\section{Milking characteristics}

During all experimental milkings the milking characteristics as calculated by the LactoPro Software (Version 5.2.0 Beta 49 software; WMB AG, 9436 Balgach, Switzerland, 2007) were used for evaluation of milk flow curves. The parameters used were total milk yield (TMY), main milking time $1\left(\mathrm{MMT}_{1}\right.$, time from milk flow $>0.5 \mathrm{~kg} / \mathrm{min}$ at the start of milking until $<0 \cdot 2 \mathrm{~kg} / \mathrm{min}$ at the end of milking), peak flow rate (PFR, highest milk flow, which is maintained for at least $22 \mathrm{~s}$ ), time until peak flow rate (tPFR), average milk flow during MMT1 (AMF), duration of incline (dl, duration from a milk flow of $0.5 \mathrm{~kg} / \mathrm{min}$ at the start of milking until milk flow reached a plateau, i.e. the slope of the increasing milk flow reached a threshold of $<0 \cdot 8 \mathrm{~kg} / \mathrm{min}^{2}$ ), duration of plateau $(\mathrm{dP}$, after incline until milk flow dropped to a slope of $>0.8 \mathrm{~kg} / \mathrm{min}^{2}$ ) and duration of decline ( $\mathrm{dD}$, after plateau until $0 \cdot 2 \mathrm{~kg} / \mathrm{min}$ ) and the occurrence of bimodal milk flow (BIMO, milk flow $>0.5 \mathrm{~kg} / \mathrm{min}$, a decline of $>0.2 \mathrm{~kg} / \mathrm{min}$ and an increase of $>0.5 \mathrm{~kg} / \mathrm{min}$ within $38 \mathrm{~s}$ after the decline).

An additional parameter not included in the LactoPro software was introduced. Main milking time $2\left(\mathrm{MMT}_{2}\right.$, time recorded from $>0.5 \mathrm{~kg} / \mathrm{min}$ until $<0.5 \mathrm{~kg} / \mathrm{min}$ ) was 
used to detect a potential treatment effect on milking time if the cluster would be removed at a higher milk flow level. $\mathrm{MMT}_{2}$ was calculated manually from the milk flow curves.

\section{Mathematical and statistical evaluations}

The herd was subdivided into three groups based on the individual peak flow rate in the treatment $\mathrm{PS}+\mathrm{MB}-$. In group 1 the PFR was $<3 \cdot 2 \mathrm{~kg} / \mathrm{min}$, in group 2 between $3 \cdot 2$ and $4.5 \mathrm{~kg} / \mathrm{min}$, and in group $3>4.5 \mathrm{~kg} / \mathrm{min}$.

All data are presented as means and SEM for the herd, for each group separately and for the different treatments. For the statistical evaluation a Mixed Procedure of SAS (Release 8.02) was used. The model contained the treatment, time of milking, stage of lactation, animal group and the individual cow as the repeated subject. None of the interactions included in the model (treatment $\times$ animal group, treatment $\times$ milking time and treatment $\times$ stage of lactation) were significant. They were therefore excluded from the model. Differences of least squares means were localized by $t$ test and considered significant if $P<0 \cdot 05$. Treatment differences with respect to the frequency of occurrence of bimodalities were tested for significance $(P<0 \cdot 05)$ by using a Multtest Procedure of SAS.

\section{Results}

TMY did not differ significantly between treatments (Tables 2, 3). In group 1 TMY was lower than in group 2 and than in group 3 , and the value in early lactation was higher than mid and late lactation, and mid was higher than late lactation $(P<0 \cdot 05)$. At morning milking TMY was significantly higher than at evening milking at a herd level and in all groups. In group 1 TMY was significantly lower in early and late compared with mid lactation. In group 2 TMY was higher in early than in mid and late lactation $(P<0 \cdot 05)$. If all experimental animals were considered, $\mathrm{AMF}$ was significantly lower in $\mathrm{PS}-\mathrm{MB}-$ than in $\mathrm{PS}+1$ $\mathrm{MB}-$ and $\mathrm{PS}+\mathrm{MB}+$. $\mathrm{PS}+\mathrm{MB}+$ had the highest values. In group 1 AMF was significantly lower than in groups 2 and 3 , in group 2 AMF was lower than in group 3. At a herd level, AMF was higher in early lactation than in mid and late lactation, and in mid lactation AMF was higher than in late lactation $(P<0 \cdot 05)$. Within groups 2 and 3 AMF was higher $(P<0 \cdot 05)$ in $\mathrm{PS}+/ \mathrm{MB}+$ than in $\mathrm{PS}-/ \mathrm{MB}-$. In group 1 no significant difference could be observed. Although differences were often non-significant, highest values of AMF were observed in all animal groups (groups 1,2, 3 and the herd) in treatment $\mathrm{PS}+\mathrm{MB}+$, followed by $\mathrm{PS}+/ \mathrm{MB}$ - and PS-MB - (Tables 2, 3). AMF was significantly lower in early and late compared with mid lactation in group 1 $(P<0 \cdot 05)$. In group 2 AMF was lower in early than in mid and late lactation, and in group 3 AMF was highest for early compared with mid and finally late lactation $(P<$ 0.05). At morning milking AMF was significantly higher at a herd level and in all groups.
Table 2. Milk flow traits of different treatments in the herd

\begin{tabular}{lllll} 
& & \multicolumn{3}{c}{ Herd } \\
\cline { 3 - 5 } Traitt & Units & PS+/MB - & PS+/MB + & PS $-/ M B-$ \\
TMY & {$[\mathrm{kg}]$} & $14 \cdot 6 \pm 0 \cdot 3$ & $14 \cdot 8 \pm 0 \cdot 3$ & $14 \cdot 4 \pm 0 \cdot 3$ \\
AMF & {$[\mathrm{kg} / \mathrm{min}]$} & $2 \cdot 64 \pm 0 \cdot 05^{\mathrm{a}}$ & $2 \cdot 74 \pm 0 \cdot 06^{\mathrm{a}}$ & $2 \cdot 56 \pm 0 \cdot 05^{\mathrm{b}}$ \\
PFR & {$[\mathrm{kg} / \mathrm{min}]$} & $4 \cdot 07 \pm 0 \cdot 09^{\mathrm{a}}$ & $4 \cdot 40 \pm 0 \cdot 09^{\mathrm{b}}$ & $4 \cdot 13 \pm 0 \cdot 09^{\mathrm{a}}$ \\
tPFR & {$[\mathrm{min}]$} & $2 \cdot 16 \pm 0 \cdot 07^{\mathrm{a}}$ & $2 \cdot 16 \pm 0 \cdot 07^{\mathrm{a}}$ & $2 \cdot 38 \pm 0 \cdot 06^{\mathrm{b}}$ \\
dl & {$[\mathrm{min}]$} & $0 \cdot 86 \pm 0 \cdot 02^{\mathrm{a}}$ & $0 \cdot 98 \pm 0 \cdot 03^{\mathrm{b}}$ & $1 \cdot 08 \pm 0 \cdot 03^{\mathrm{c}}$ \\
dP & {$[\mathrm{min}]$} & $1 \cdot 96 \pm 0 \cdot 08^{\mathrm{a}}$ & $1 \cdot 72 \pm 0 \cdot 08^{\mathrm{b}}$ & $1 \cdot 82 \pm 0 \cdot 08^{\mathrm{ab}}$ \\
dD & {$[\mathrm{min}]$} & $2 \cdot 70 \pm 0 \cdot 07$ & $2 \cdot 72 \pm 0 \cdot 08$ & $2 \cdot 70 \pm 0 \cdot 07$ \\
MMT1 & {$[\mathrm{min}]$} & $5 \cdot 51 \pm 0 \cdot 10$ & $5 \cdot 42 \pm 0 \cdot 10$ & $5 \cdot 60 \pm 0 \cdot 09$ \\
MMT2 & {$[\mathrm{min}]$} & $5 \cdot 30 \pm 0 \cdot 10$ & $5 \cdot 23 \pm 0 \cdot 10$ & $5 \cdot 39 \pm 0 \cdot 09$ \\
BIMO & {$[\%]$} & $21 \cdot 9 \pm 3 \cdot 2^{\mathrm{a}}$ & $24 \cdot 8 \pm 3 \cdot 4^{\mathrm{a}}$ & $45 \cdot 2 \pm 3 \cdot 9^{\mathrm{b}}$
\end{tabular}

abc Values in the same row without common superscript are significantly different $(P<0 \cdot 05)$

+ See text for definitions of abbreviations

PFR was significantly higher (Fig. 1) in treatment PS+/ $\mathrm{MB}+$ than in the other treatments in groups 2 and 3 . PFR in treatments PS+/MB - and PS-/MB - did not differ significantly. Only in group 1 , the cows with the lowest PFR $(<3 \cdot 2 \mathrm{~kg} / \mathrm{min})$, PFR did not significantly differ between any treatments (Tables 2,3). PFR was lower in group 1 than in group 2 and group 3, respectively. PFR was higher at morning than at evening milkings and higher in early and mid compared with late lactation $(P<0 \cdot 05)$. In group 2 PFR was significantly lower in early than in mid and late lactation and PFR was significantly higher in early compared with mid and compared with late lactation.

tPFR was significantly longer in group 2 in PS-/MBcompared with the other treatments (Table 3). tPFR was longer in group 1 compared with groups 2 and 3 and in group 2 compared with group $3(P<0 \cdot 05)$. tPFR was higher in early and mid lactation than in late lactation $(P<0 \cdot 05)$. tPFR was significantly shorter in early than in mid and late lactation in group 1 . In group 3 tPFR was significantly higher in early and mid lactation compared with late lactation.

Duration of incline over the whole herd was significantly different between all treatments. dl was longer in group 2 compared with groups 1 and 3 and it was shorter during evening than morning milkings $(P<0 \cdot 05)$. A significant difference was seen in groups 1 and 2 between $\mathrm{PS}-/ \mathrm{MB}-$ and $\mathrm{PS}+/ \mathrm{MB}-$ and in group 3 in $\mathrm{PS}+/ \mathrm{MB}-$ compared with $\mathrm{PS}-\mathrm{MB}-$ and $\mathrm{PS}+/ \mathrm{MB}+$. In all groups and consequently over the whole herd, $\mathrm{dl}$ was shortest in $\mathrm{PS}+$ / $\mathrm{MB}-$, followed by PS+/MB+ and PS-/MB - (Tables 2, 3). In group $1 \mathrm{dl}$ was longer for early and late lactation compared with mid lactation, whereas in group $2 \mathrm{dl}$ was higher at evening than morning milkings $(P<0 \cdot 05)$. $\mathrm{dl}$ was shorter in early and mid lactation than in late lactation in group 2 and in group 3 it was longer for early and mid compared with late lactation $(P<0 \cdot 05)$. 
Table 3. Milk flow traits of different treatments in different groups

\begin{tabular}{|c|c|c|c|c|c|c|c|c|c|c|}
\hline \multirow[b]{2}{*}{ Traitt } & \multirow[b]{2}{*}{ Units } & \multicolumn{3}{|c|}{ Group 1} & \multicolumn{3}{|c|}{ Group 2} & \multicolumn{3}{|c|}{ Group 3} \\
\hline & & $\mathrm{PS}+/ \mathrm{MB}-$ & $\mathrm{PS}+/ \mathrm{MB}+$ & $\mathrm{PS}-/ \mathrm{MB}-$ & $\mathrm{PS}+/ \mathrm{MB}-$ & $\mathrm{PS}+/ \mathrm{MB}+$ & $\mathrm{PS}-/ \mathrm{MB}-$ & $\mathrm{PS}+/ \mathrm{MB}-$ & $\mathrm{PS}+/ \mathrm{MB}+$ & $\mathrm{PS}-/ \mathrm{MB}-$ \\
\hline TMY & {$[\mathrm{kg}]$} & $12 \cdot 2 \pm 0 \cdot 3$ & $12 \cdot 2 \pm 0 \cdot 2$ & $11 \cdot 8 \pm 0 \cdot 3$ & $14 \cdot 1 \pm 0 \cdot 4$ & $14 \cdot 6 \pm 0 \cdot 4$ & $14 \cdot 1 \pm 0 \cdot 4$ & $17 \cdot 3 \pm 0 \cdot 7$ & $17 \cdot 3 \pm 0 \cdot 7$ & $17 \cdot 0 \pm 0 \cdot 7$ \\
\hline AMF & {$[\mathrm{kg} / \mathrm{min}]$} & $1.97 \pm 0.03$ & $2 \cdot 02 \pm 0 \cdot 04$ & $1 \cdot 92 \pm 0.04$ & $2 \cdot 52 \pm 0 \cdot 04^{\mathrm{ab}}$ & $2 \cdot 63 \pm 0 \cdot 05^{b}$ & $2 \cdot 44 \pm 0 \cdot 04^{\mathrm{a}}$ & $3 \cdot 40 \pm 0 \cdot 08^{\mathrm{ab}}$ & $3 \cdot 48 \pm 0 \cdot 08^{\mathrm{a}}$ & $3 \cdot 27 \pm 0 \cdot 08^{b}$ \\
\hline PFR & {$[\mathrm{kg} / \mathrm{min}]$} & $2 \cdot 81 \pm 0 \cdot 04$ & $2.97 \pm 0.05$ & $2 \cdot 87 \pm 0.06$ & $3 \cdot 97 \pm 0.05^{\mathrm{a}}$ & $4 \cdot 32 \pm 0 \cdot 05^{\mathrm{b}}$ & $4 \cdot 01 \pm 0 \cdot 05^{a}$ & $5 \cdot 38 \pm 0 \cdot 10^{\mathrm{a}}$ & $5 \cdot 70 \pm 0 \cdot 08^{\mathrm{b}}$ & $5 \cdot 40 \pm 0 \cdot 09^{a}$ \\
\hline tPFR & [min] & $2 \cdot 60 \pm 0 \cdot 14$ & $2 \cdot 72 \pm 0 \cdot 15$ & $2 \cdot 66 \pm 0 \cdot 13$ & $2 \cdot 17 \pm 0 \cdot 10^{a}$ & $2 \cdot 01 \pm 0 \cdot 08^{a}$ & $2 \cdot 42 \pm 0 \cdot 07^{b}$ & $1 \cdot 72 \pm 0 \cdot 13$ & $1 \cdot 86 \pm 0 \cdot 10$ & $2 \cdot 07 \pm 0 \cdot 09$ \\
\hline dl & [min] & $0 \cdot 84 \pm 0 \cdot 04^{a}$ & $0 \cdot 93 \pm 0 \cdot 04^{\mathrm{ab}}$ & $1 \cdot 02 \pm 0 \cdot 05^{\mathrm{b}}$ & $0.91 \pm 0.03^{a}$ & $1 \cdot 03 \pm 0.05^{\mathrm{ab}}$ & $1 \cdot 12 \pm 0.06^{\mathrm{b}}$ & $0 \cdot 80 \pm 0.05^{a}$ & $0.95 \pm 0.05^{b}$ & $1 \cdot 07 \pm 0 \cdot 06^{b}$ \\
\hline $\mathrm{dP}$ & {$[\mathrm{min}]$} & $2 \cdot 72 \pm 0 \cdot 13$ & $2 \cdot 54 \pm 0 \cdot 14$ & $2 \cdot 62 \pm 0 \cdot 14$ & $1 \cdot 86 \pm 0 \cdot 10$ & $1 \cdot 52 \pm 0 \cdot 10$ & $1 \cdot 72 \pm 0 \cdot 11$ & $1 \cdot 40 \pm 0 \cdot 13$ & $1 \cdot 27 \pm 0 \cdot 14$ & $1 \cdot 25 \pm 0 \cdot 11$ \\
\hline $\mathrm{dD}$ & {$[\mathrm{min}]$} & $2 \cdot 54 \pm 0 \cdot 14$ & $2 \cdot 53 \pm 0 \cdot 18$ & $2 \cdot 48 \pm 0 \cdot 15$ & $2 \cdot 78 \pm 0 \cdot 13$ & $2 \cdot 96 \pm 0 \cdot 14$ & $2 \cdot 88 \pm 0 \cdot 13$ & $2 \cdot 74 \pm 0.07$ & $2 \cdot 59 \pm 0.09$ & $2 \cdot 69 \pm 0 \cdot 08$ \\
\hline MMT1 & {$[\mathrm{min}]$} & $6 \cdot 09 \pm 0 \cdot 15$ & $6 \cdot 01 \pm 0 \cdot 16$ & $6 \cdot 12 \pm 0 \cdot 17$ & $5 \cdot 55 \pm 0 \cdot 17$ & $5 \cdot 52 \pm 0 \cdot 17$ & $5 \cdot 72 \pm 0 \cdot 16$ & $4 \cdot 94 \pm 0 \cdot 15$ & $4 \cdot 81 \pm 0 \cdot 14$ & $5 \cdot 01 \pm 0 \cdot 12$ \\
\hline MMT2 & {$[\mathrm{min}]$} & $6 \cdot 08 \pm 0 \cdot 16$ & $5 \cdot 96 \pm 0 \cdot 16$ & $6 \cdot 09 \pm 0 \cdot 17$ & $5 \cdot 20 \pm 0 \cdot 15$ & $5 \cdot 26 \pm 0 \cdot 15$ & $5 \cdot 34 \pm 0 \cdot 15$ & $4 \cdot 70 \pm 0 \cdot 15$ & $4 \cdot 58 \pm 0 \cdot 14$ & $4 \cdot 82 \pm 0 \cdot 12$ \\
\hline BIMO & {$[\%]$} & $20 \cdot 8 \pm 5 \cdot 9^{\mathrm{a}}$ & $15 \cdot 2 \pm 5 \cdot 4^{a}$ & $41 \cdot 7 \pm 7 \cdot 2^{b}$ & $20 \cdot 3 \pm 4 \cdot 9^{a}$ & $27 \cdot 7 \pm 5 \cdot 6^{\mathrm{a}}$ & $48 \cdot 5 \pm 6 \cdot 2^{b}$ & $25 \cdot 0 \pm 6 \cdot 1^{a}$ & $29 \cdot 6 \pm 6 \cdot 3^{\mathrm{ab}}$ & $44 \cdot 4 \pm 6 \cdot 8^{b}$ \\
\hline
\end{tabular}

ab Values in the same group without common superscript are significantly different $(P<0 \cdot 05)$ + See text for definitions of abbreviations
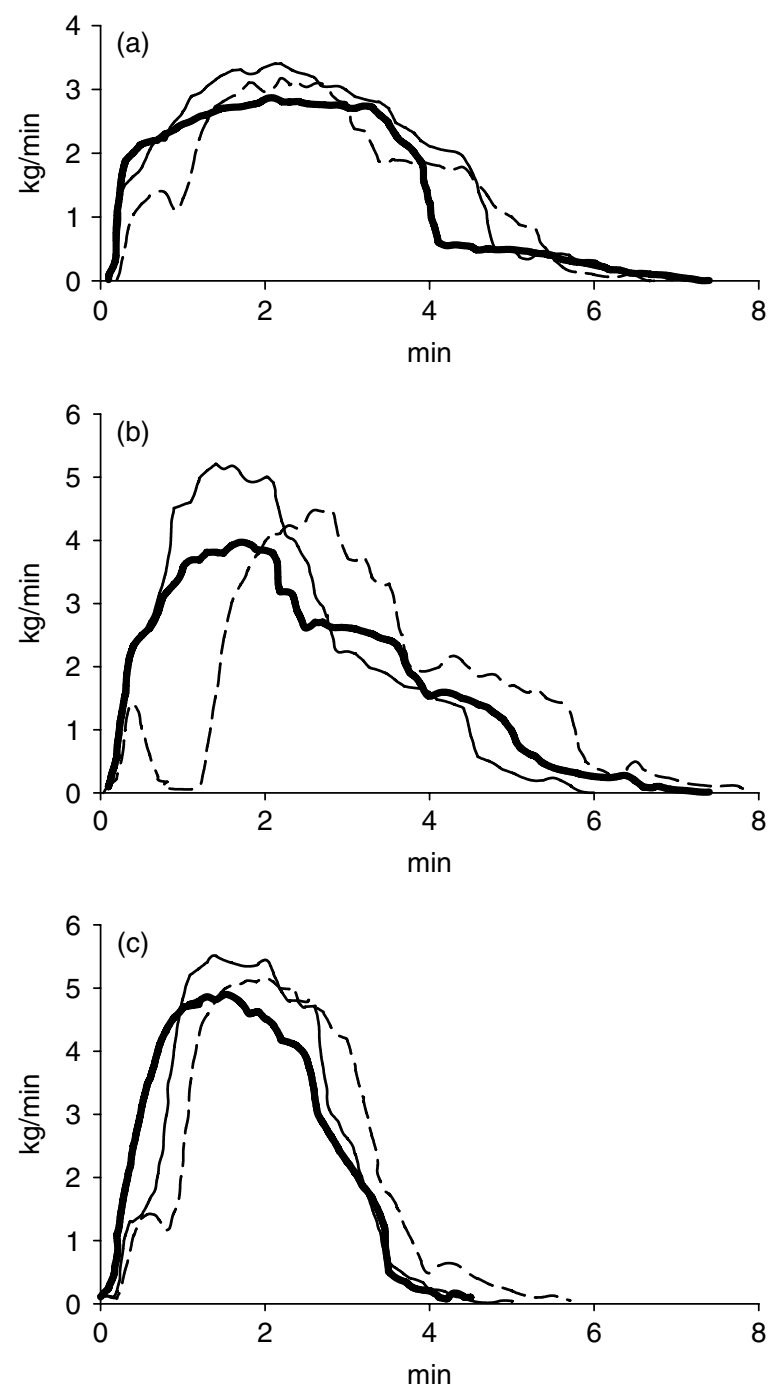

Fig. 1. Milk flow curves of a cow of group $1=\mathrm{PFR}<3 \cdot 2 \mathrm{~kg} / \mathrm{min}$ (a), of group $2=$ PFR $3 \cdot 2-4 \cdot 5 \mathrm{~kg} / \mathrm{min}$ (b) and of group $3=\mathrm{PFR}>$ $4.5 \mathrm{~kg} / \mathrm{min}$ (c) with the different treatments (PS+/MB-: $\mathrm{PS}+/ \mathrm{MB}+$ : -; $\mathrm{PS}-/ \mathrm{MB}-$ : --). PS: pre-stimulation; $\mathrm{MB}$ : milk flow-controlled b-phase.
Both duration of plateau $(\mathrm{dP})$ and duration of decline (dD) did not significantly differ among the treatments. Except for the herd, dP was significantly longer for PS+/ $\mathrm{MB}+$ than $\mathrm{PS}+\mathrm{MB}-. \mathrm{dP}$ was longer in group 1 than in group 2 and than in group $3(P<0 \cdot 05)$. $\mathrm{dD}$ was shorter in group 1 than in group 2 and for early lactation $\mathrm{dP}$ was higher than mid and late lactation, and mid was higher than late lactation $(P<0 \cdot 05)$. At evening milkings $\mathrm{dP}$ was always significantly shorter for all animals and for all groups. In group $1 \mathrm{dP}$ was significantly longer in early than late lactation, in group 2 it was significantly shorter in early than in mid and late lactation, and in group 3 it was significantly longer in early compared with mid and at the end late lactation. $\mathrm{dD}$ was shorter in early and mid lactation compared with late lactation for group 1, while in group $2 \mathrm{dD}$ was higher in early compared with mid and late lactation and in group 3 it was shorter for early and late lactation as compared with mid lactation $(P<$ 0.05).

$M M T_{1}$ and $M M T_{2}$ were not significantly different between the different treatments (Fig. 1). In all groups (except for $\mathrm{MMT}_{2}$ in group 2) and over the whole herd both parameters were numerically shortest in $\mathrm{PS}+\mathrm{MB}+$, followed by $\mathrm{PS}+/ \mathrm{MB}$ - and then PS-/MB - (Tables 2, 3). $\mathrm{MMT}_{1}$ and $\mathrm{MMT}_{2}$ were longer in group 1 compared with group 2 and at the end group 3 , and in early lactation they were longer than in mid and late lactation and mid were longer than late lactation $(P<0 \cdot 05) . \mathrm{MMT}_{1}$ and $\mathrm{MMT}_{2}$ were significantly shorter during evening than during morning milkings at a herd level and all groups except for $\mathrm{MMT}_{1}$ in group 2. In group $2 \mathrm{MMT}_{1}$ and $\mathrm{MMT}_{2}$ were longer for early compared with mid and late lactation and in group 3 they were longer for early and mid compared with late lactation $(P<0 \cdot 05)$.

Bimodality was most frequent in $\mathrm{PS}-\mathrm{MB}-$ followed by $\mathrm{PS}+/ \mathrm{MB}+$ (except group 1) and PS+/MB - (Fig. 1). In group 1 the frequency of bimodality was significantly higher in PS $-/ M B$ - than in PS+/MB - and PS+/MB+. In group 2 and over the whole herd it was higher in $\mathrm{PS}-\mathrm{MBB}$ - than in 
$\mathrm{PS}+/ \mathrm{MB}+$ and $\mathrm{PS}+/ \mathrm{MB}-(P<0 \cdot 05)$. In group 3 it was significantly more frequent in $\mathrm{PS}-/ \mathrm{MB}-$ than in $\mathrm{PS}+/ \mathrm{MB}-$.

\section{Discussion}

TMY did not change throughout the experiment. This indicates complete emptying of the mammary gland in every treatment and for every group.

AMF did not differ between treatments in all groups (except in group 2 between $\mathrm{PS}+/ \mathrm{MB}+$ and $\mathrm{PS}-/ \mathrm{MB}-$ ). Thus, even if there was a higher PFR in all observed groups and all over the groups (herd) AMF and TMY remained unchanged. This is in contrast to the report by Spencer et al. (2007), where AMF augmented with elevating ratio. Obviously, the milk ejection rate, i.e. the rate of milk transferred from the alveolar tissue into the cisternal cavities, is a limiting factor for the milk flow rate (Pfeilsticker et al. 1995). At the start of milking the cistern is well filled with milk and the milk ejection rate is high owing to wellfilled alveoli. Therefore, the milk flow rate during this period is mainly determined by the teat anatomy and specifications of liner, pulsation, and vacuum (Thomas et al. 1991; Pfeilsticker et al. 1995; Hamann \& Mein, 1996; Weiss et al. 2004; Spencer et al. 2007). In contrast, towards the end of milking, the delivery of milk from the secretory tissue in the cistern is slowing down owing to the gradual emptying of the alveoli, i.e. the milk ejection rate is decreasing. This process cannot be influenced by adjustments of the milking machine and the milk ejection rate can be a major limiting factor for the milk flow towards the end of milking, and a flat decline of milk flow in each quarter probably represents the decline of milk ejection (Pfeilsticker et al. 1995). In PS+/MB+ peak flow rates were higher than in $\mathrm{PS}-/ \mathrm{MB}-$ or in $\mathrm{PS}+/ \mathrm{MB}-$. If milking was performed with milk flow-controlled b-phase $(\mathrm{PS}+/ \mathrm{MB}+)$ the pulsation ratio increased and the pulsation rate declined, causing an overall elongated liner-open time if ample milk was present in the cisternal cavities. As long as this situation was maintained, the milk flow rate could be increased in response to a longer liner-open phase. Potentially it is possible that the increase in milk flow could prevent the liner from closing and could cause oedema. But high milk flow lasts only about 2-3 min and then the machine is already changing the pulsation ratio and rate, and therefore there would be minimal oedema. Milking with milk flow-controlled b-phase is even more gentle on the teat because of the changing pulsation ratio and rate. Owing to the increase of the pulsation ratio, PFR soars as long as a buffer of milk is available in the cistern (Pfeilsticker et al. 1995; Hamann \& Mein, 1996; Spencer et al. 2007). tPFR occurred later (except for group 2) and dl was longer than can be explained by a higher level of PFR which needed to be reached stepwise in the treatment with gradually elongated b-phase. Because TMY and AMF did not change a lot between the different treatments, MMT1 remained unchanged $\left(\mathrm{MMT}_{1}\right.$ lasted until $\left.0 \cdot 2 \mathrm{~kg} / \mathrm{min}\right)$. If the milk ejection rate becomes limiting for milk flow towards the end of milking, it seems possible that the final period of milking at very low milk flow rates $<0.5 \mathrm{~kg} / \mathrm{min}$ has a great effect on the remaining milking time. Therefore a difference between treatments seemed possible if the clusters would be removed already at $0.5 \mathrm{~kg} / \mathrm{min}\left(\mathrm{MMT}_{2}\right)$. However, also at this higher level of potential cluster removal no treatment differences were observed. Bimodality of milk flow was most frequent in $\mathrm{PS}-\mathrm{MB}-$. This is allegedly due to a delayed occurrence of milk ejection while the cisternal milk is close to being completely removed. As repeatedly shown (Mayer et al. 1984; Bruckmaier \& Blum, 1996; Weiss et al. 2003) a not-fully pre-stimulated cow shows a transient reduction of milk flow (bimodality), after the cisternal part is milked out and before the milk ejection occurs.

Effects on PFR and dl were more distinct in the two groups with higher PFR (groups 2 and 3) than in the group with the lowest PFR (group 1).

In conclusion, adaptation of the b-phase on the milk flow $(\mathrm{PS}+/ \mathrm{MB}+)$ causes an increased milk flow rate most pronounced in animals that already show high milk flow rate under standard conditions. This effect is, however, only present as long as milk is available in the cisternal cavities. In particular, towards the end of milking the rate of milk ejection can become a limiting factor for milk flow. During this period, an adaptation of the b-phase on the milk flow $(\mathrm{PS}+/ \mathrm{MB}+)$ has no effect. Therefore, the performed adaptations ( $\mathrm{PS}+/ \mathrm{MB}+$ ) have mainly an effect on PFR and not on AMF and total milking time.

Bimodality was most frequently seen in milking with a minimum of teat cleaning and without milk flow controlled b-phase (PS-/MB-).

\section{References}

Ayadi M, Caja G, Such X \& Knight CH 2003 Use of ultrasonography to estimate cistern size and milk storage at different milking intervals in the udder of diary cows. Journal of Dairy Research 70 1-7

Ayadi M, Caja G, Such X, Rovai M \& Albanell E 2004 Effect of different milking intervals on the composition of cisternal and alveolar milk in dairy cows. Journal of Dairy Research 71 304-310

Bruckmaier RM, Schams D \& Blum JW 1994a Continuously elevated concentrations of oxytocin during milking are necessary for complete milk removal in dairy cows. Journal of Dairy Research 61 323-334

Bruckmaier RM, Rothenanger E \& Blum JW 1994b Measurements of mammary gland cistern size and determination of the cisternal milk fraction in dairy cows. Milchwissenschaft 49 543-546

Bruckmaier RM \& Blum JW 1996 Simultaneous recording of oxytocin release, milk ejection and milk flow during milking of dairy cows with and without prestimulation. Journal of Dairy Research 63 201-208

Bruckmaier RM 2005 Normal and disturbed milk ejection in dairy cows. Domestic Animal Endocrinology 29 268-273

Gleeson DE, O'Callaghan EJ \& Rath MV 2004 Effect of liner design, pulsator setting, and vacuum level on bovine teat tissue changes and milking characteristics as measured by ultrasonography. Irish Veterinary Journal 57 289-296

Hamann J \& Mein GA 1996 Teat thickness changes provide biological test for effective pulsation. Journal of Dairy Research 63 179-189 
Mayer H, Schams D, Worstorff H \& Prokopp A 1984 Secretion of oxytocin and milk removal as affected by milking cows with and without manual stimulation. Journal of Endocrinology 103 355-361

Pfeilsticker HU, Bruckmaier RM \& Blum JW 1995 Interruption of machine milking in dairy cows: effects on intramammary pressure and milking characteristics. Journal of Dairy Research 62 559-566

Pfeilsticker HU, Bruckmaier RM \& Blum JW 1996 Cisternal milk in dairy cow during lactation and after preceding teat stimulation. Journal of Dairy Research 63 509-515

Sandrucci A, Tamburini A, Bava L \& Zucali M 2007 Factors affecting milk flow traits in dairy cows: Results of a field study. Journal of Dairy Science 90 1159-1167

Schams D, Mayer H, Prokopp A \& Worstorff H 1984 Oxytocin secretion during milking in dairy cows with regard to the variation and importance of a threshold level for milk removal. Journal of Endocrinology $102337-343$
Smith VR \& Petersen WE 1946 The effect of increasing the negative pressure and widening of the vacuum-release ratio on the rate of removal of milk from the udder. Journal of Dairy Science 29 45-53

Spencer SB, Shin JW, Rogers GW \& Cooper JB 2007 Short Communication: Effect of vacuum and ratio on the performance of a monoblock silicone milking liner. Journal of Dairy Science $\mathbf{9 0}$ 1725-1728

Thomas CV, Force DK, Bremel DH \& Strasser S 1991 Effects of pulsation ratio, pulsation rate, and teatcup liner design on milking rate and milk production. Journal of Dairy Science 74 1243-1249

Weiss D, Dzidic A \& Bruckmaier RM 2003 Effect of stimulation intensity on oxytocin release before, during and after machine milking. Journal of Dairy Research 70 349-354

Weiss D, Weinfurtner M \& Bruckmaier RM 2004 Teat anatomy and its relationship with quarter and udder milk flow characteristics in dairy cows. Journal of Dairy Science 87 3280-3289 